\title{
Star Making: A Publishing History of Thea Astley
}

\author{
Deborah Jordan
}

Monash University

$\&$

Louise Poland

Monash University

\begin{abstract}
This article focuses directly on Thea Astley's publishing history from the time of her involvement with Brisbane's avant garde in the 1950s, her early inclusion in regional collections, and her emergence as a Miles Franklin prize-winning author, through the enabling pen and advocacy of one of Angus \& Robertson (A\&R)'s finest fiction editors, Beatrice Davis, to the establishment in the 1980s of Astley's ultimate author-publisher relationship with Penguin Books and her own overseas literary agent. It will also examine the publishing trajectory of selected novels released and re-issued by the University of Queensland Press (UQP) and Penguin Books, and revisit the divides between writer and editor, publisher and publicist, and the dis/enabling inspiration of difference in the tropics, in the context of the gendered histories of publishing at A\&R, Penguin Books and UQP.
\end{abstract}

'I often wonder if this star-making thing is achieved by writers who deliberately court it' (Thea Astley,1986)

$\mathrm{T}$ hea Astley is a critically acclaimed, prize-winning Australian novelist and short fiction writer, whose extraordinary literary career spans more than fifty years from the late 1950s to 2004. She always, according to a major study of her work, 'set her fiction in the tropics and mostly her heartland of North Queensland' (Sheridan and Genoni, xiii). Her reputation as a social critic is established; she is renowned for 'her sharp yet compassionate portrayal of social outsiders' and 'the mordant irony of her gaze on Australian society' (xi). On the other hand, however, she is still little known to the general public. In the following pages we will begin to address this anomaly; we will broaden the focus on Thea Astley and her writings to include the wider literary field to locate Astley as an author in a network of relationships, particularly with editors and publishers. ${ }^{1}$

The broad sweep of Astley's publishing history is strikingly representative of many writers' trajectories in the halcyon days of publishing in Australia from 1965 to 1995 ; $^{2}$ indeed it

\footnotetext{
${ }^{1}$ In this preliminary article on Thea Astley's publishing history, we draw on some valuable source materials. Floods destroyed Jacaranda's records, but the archives of Angus \& Robertson, UQP and Penguin remain intact and are extremely rich.

${ }^{2}$ This paper arises from a wider project, 'Australian Literary Publishing and its Economies, 1965-1995'. We would like to thank UQP and Penguin Books for access to their archival files.
} 
parallels many of the major structural changes taking place in Australian publishing. The prestigious Sydney-based firm Angus \& Robertson (A\&R) first published Astley's novels in the late 1950s through to the 1970s; one of these A\&R novels was republished in the mid1960s by Sun Books in Melbourne, and the American firm M. Evans. When A\&R was reshaped in 1973 Astley travelled with her editor, Beatrice Davis, to Thomas Nelson (she was also published by Jacaranda in Queensland). Astley then approached the University of Queensland Press (UQP), which republished two of her A\&R novels and went on to publish her next novel. Penguin Books Australia picked up paperback rights to Astley's Thomas Nelson hardbacks, and also courted her. With subsequent territorial rights splitting, and the increasing use of literary agents, the picture becomes more complex, and Astley went on to publish with Penguin and Heinemann. In the search for an overseas audience Astley was published by Penguin associates, that is Viking in the US, Penguin in UK, and later directly into the American market by Putman. By then she had her own international agent.

Yet, the publishing histories of Astley's books are not entirely typical due to the gendered nature of publishing. In a recent discussion of Astley's progression as a writer, Susan Sheridan suggests that Brisbane in the 1950s was a backwater (51ff), and observes that it is rather surprising to find a teacher, and a woman, emerging from Brisbane to become one of Australia's most significant writers of the latter half of the twentieth century. But if Brisbane was a literary backwater, what of the tropical far north where Astley worked as a teacher in the mid-1940s, of Cairns and Kuranda where she chose to retire in the 1980s, and where her novels were often set?

Susan Lever has framed Astley as a 'ratbag novelist', 'passionate and opinionated' (16) because of her 'isolation' while living in North Queensland where her ideas went unchallenged. But Astley does not fit the stereotype of the reclusive writer; her style was surely honed firstly in the combative arena of teaching adolescents, and then in collaboration with her editors. We seek therefore to address Astley's crucial relationships with Beatrice Davis at A\&R, with UQP, and finally with Penguin Books.

Moreover, Queensland was no literary backwater, especially at the formative time in Astley's career when she began to write regularly. Even before that, her father Cec Astley was a longterm sub-editor at the Courier in the days when links between professional writers and newspapers were strong. When Astley was only fifteen years old, Queensland was the centre of several hundred thousand World War Two army personnel stationed at the American centre for operations in the Pacific; the 'American rape' Astley called it (in Whitlock, 79). War is always a time of heightened distinctions between the genders, and of polarised gender roles. Those creative, heady and urgent days also saw the establishment of Meanjin by Clem Christensen (in the Courier office), the influence of European modernisms and experiment introduced by the European refugees, notably Gertrude Langer, and Barjai, a radical student journal and social network. The Barjai group nurtured Astley, the aspiring poet, who published frequently in the near-monthly magazine (Taylor, 5-6); this group, writes Pat Buckridge, were mentored in part by Douglas Stewart of the Bulletin (61). Here, it was Astley's meeting with Paul Grano, the Catholic poet, that led to her important realisation that one could make a lyric argument out of Cleveland, or Smithfield (in Whitlock, 172).

Thea Astley was 23 when she left Brisbane and moved to Sydney in 1948. Down south, she learnt to 'tear' into Queensland, that is, as she wrote in 1976, 'publically demolish' 
Queensland while also privately adoring it (in Whitlock, 173). In many ways this captures what was to become an ongoing tension in Astley's work and freed her up for her pitiless social critique. Astley 'gives her characters another alternative, Eden' writes Elaine Lindsay (111), even if it can never be fully attained 'because of the fallenness of humanity' (116). Ultimately Astley was to create a cast of characters who represent as 'many spiritual responses to the tropics' (117) as varieties or particularities of individuals.

In the late 1950s, while Astley was working as a teacher and living with her accountant husband in Sydney, Beatrice Davis wrote to ask that she contact her. This was a highly unusual initiative for Davis who often remarked that 'it wouldn't do' for her to approach an author. Davis was 'effectively the literary publisher of A\&R as well as its chief editor' (Kent, 178) and she was enamoured by Astley's unique voice. A\&R published Astley's first novel, Girl with a Monkey in 1958, followed by a series of novels, A Descant for Gossips, The WellDressed Explorer, The Slow Natives, A Boatload of Home Folk, The Acolyte, from 1960 to 1972, three of which won (or shared) the Miles Franklin Award. ${ }^{3}$ Astley and Davis edited these manuscripts face to face, and Astley subsequently credited Davis with teaching her how to develop her strengths as a writer:

To me Beatrice Davis was Angus \& Robertson ... [She] has the capacity to advise without hurt, to correct without making the author feel ashamed or inadequate. This is a truly rare gift. Beatrice had a way of turning corrections into a joke-('I think we'll have a teeny piece of comma here!') - that entirely negated any feeling of inadequacy on the writer's part. Beatrice Davis has taught me more about writing than anyone else. (Tribute, 1974).

Although, as scholar Karen Lamb finds (53ff), Patrick White may have offered Astley timely advice on novel writing, it was the enabling pen and advocacy of Davis, her 'compassionate care' (Stacy in Poland, 123) and the in-depth, face-to-face conversation and page-by-page assessments of Astley's manuscripts which were even more timely and formative. Moreover, Beatrice Davis's 1960s George Street Studio was in effect a 'Literary Salon' where writers engaged in professional development, or 'talked and talked' over 'an ambrosial cold meal' and a glass of wine (Poland, 129). Astley signed over world rights to A\&R; they paid her ten per cent royalties for Australasian sales, but she received very little distribution or promotion in Britain. The British publishing industry, which dominated the Australian publishing industry at that time, was not interested in Australian authors. The American publishing firm, M. Evans, however, bought US rights to the prize-winning The Slow Natives (published by A\&R in 1965). Sun Books, a new independent paperback publisher in Melbourne, also republished The Slow Natives. This was the first of Astley's novels to appear in paperback (in 1966) and the first to reach an American audience (in 1967).

Astley did not write to win recognition as an author, according to Cheryl Taylor (1), and in this she was like White, a 'literary idealist'. Astley travelled with Davis to Thomas Nelson where Davis was the Sydney-based editor of their new trade list (for seven years). Thomas Nelson published Astley's A Kindness Cup (1974) and Hunting the Wild Pineapple (1979) (in hardback as was the norm). The relationship between the older woman and the younger, the

\footnotetext{
${ }^{3}$ Astley's first A\&R publication break occurred when one of her stories was included in Coast to Coast (1950).
} 
salaried editor and unsalaried author, is inevitably an unequal one. But Astley did not need to write to earn her income as she was teaching at Macquarie University. Ultimately, however, the British-owned Thomas Nelson was no real alternative to the old A\&R for either Astley or Davis. As Robyn Sheahan-Bright points out, Thomas Nelson decided to cut back and concentrate on 'specialised works with a guaranteed market' and in 1979 it became part of the new International Thomson group (281).

Frank Thompson, UQP's publisher, had been impressed on his early reading of Astley's Girl with a Monkey, which he read at Davis's instigation. But it was not until 1980 that UQP published any of Astley's work. ${ }^{4}$ UQP had a reputation for recognising and developing talent and was the first publisher of major Australian writers such as Peter Carey and Roger McDonald, but its list comprised mostly younger men. Prior to the 1980s it took few risks with women as authors. The first UQP novel by a woman was that by the South Australian Barbara Hanrahan, who was, like Astley, was a mid-career writer (Jordan, 334). When Astley approached UQP, UQP offered to release a new edition of The Acolyte (originally published by A\&R in 1972). UQP published a paperback edition of The Acolyte in 1980 (and again in 1981, with a print run of about five and a half thousand copies of which four and a half thousand copies were sold). The following year, as ABC television was developing a miniseries adapted from A Descant for Gossips, Astley again approached UQP to suggest a new publication of that novel, (first published by A\&R in 1960, and by Jacaranda in 1969) (Yule to Astley, UQP, 4 February 1982). UQP reissued A Descant for Gossips and later reprinted it. Importantly, though, Astley also sent UQP a copy of the manuscript that was to become Item from the Late News.

Set in North Queensland, in response to her concerns about the possibility of nuclear war, and her first novel with a female narrator, Item from the Late News investigates the entrenched masculine violence in small communities in North Queensland, and the 'insane attitudes that put the planet at risk' (Pollak et al, 71). When Davis read the manuscript she advised Astley that the

devastating tragedy of it made me feel truly sick. Greed \& brutality, with Gabby the informed onlooker. I couldn't believe in her, though unhappy \& frustrated in her love, behaving with such bitter spite. Yet this is the basis of your sad tale: her inability to keep Hafen even though he wanted no one. I was deeply moved by Hafen's plight, his helplessness yet unpungability... too close to even snipe at your being at times too clever by half (Davis to Astley, Astley Collection, 11.11.82).

'What a relief to read a decent manuscript for once', wrote UQP's editor D'Arcy Randall when she received the manuscript, 'One you can't leave until the next morning to finish and want to pick up at stop lights on the way home' (Randall to Astley, UQP, 15.01.1982). A contract was drawn up which offered a generous $20 \%$ royalty, ${ }^{5}$ and an advance of $\$ 1000$. It was the first advance Astley had ever received, and she bought a washing machine. Astley took on board Randall's editorial advice to rework the novel's opening, thus making a clear

\footnotetext{
${ }^{4}$ Deborah Jordan would like to acknowledge D'Arcy Randall and Merril Thompson for a helpful discussion on the following section.

${ }^{5}$ This refers to $20 \%$ of RRP for the first 5000 copies; $22.5 \%$ for the next 5000 copies. (UQP contract).
} 
distinction between herself as the writer and Randall as the reader. They had yet to agree on a name: Astley suggested 'Losers', 'Hatters' or 'Myth-fits', later 'Tailings, 'Stalemates' 'Timepiece' 'A Sense of Direction' or 'Small Town Mosaic'. Astley also wanted an image of an atomic explosion on the novel's cover to reflect her sense of urgency and despair. Randall undertook the editing and the book was a straightforward, extremely competent, production. Astley promised her next novel to UQP but only if they found an American audience for her work.

By the late 1970s, British and American publishers had become more interested in the Australian market; many Australian writers sought readers in the United States and Britain. The established colonial publishing model was beginning to break down, but it had allowed certain initiatives. When UQP established an Australian list, it picked up the torch from A\&R. Moreover, with Frank Thompson at the helm in the 1970s, UQP's imprint pages stated 'New York, London and St Lucia'. Was this one of the reasons why Astley submitted her manuscript to UQP? This was the period that saw rights splitting, and the rise of the international literary agent, one of whose key roles was to sell territorial rights. Multinational publishers commonly set up branches in Australia to capitalise on these developments. The publisher had earlier undertaken much of the work of the literary agent, but now agents sought overseas rights sales, or co-publications with overseas publishers, and - as in the case of UQP, direct sale into the American market. ${ }^{6}$ Rights to An Item from the Late News were almost sold to Random in the United States, and Chatto and Windus in England, but when this interest came to naught, UQP's American distributors distributed run-on copies of the UQP printing in the US. An Item from the Late News was positively reviewed in the US (Bowman in Munro, 106) and 1500 hardback copies were sold. However, by March 1983 UQP had sold the Australasian paperback rights to Penguin Australia.

Astley wanted 'pizzazz' and was concerned about UQP's lack of publicity for her book (Astley to Julie Watts, Penguin, 30.09.1983). She compared the promotion of her books to those of the feted David Malouf. Astley was unaware, however, that in the very year Item from the Late News was published (1983), Frank Thompson had resigned from his twentytwo-year tenure as UQP's publisher. Rupture in the Press' management meant all kinds of difficulties, and there was no publisher at the helm until Laurie Muller took up the position nearly a year later. When an offer was made for the film rights to Item from the Late News, a low offer, Astley engaged the literary agency Curtis Brown to negotiate for her rather than UQP. To UQP's surprise, she also asked for the return of rights to The Acolyte, even though the book was still in print. UQP's new publisher Laurie Muller replied to her at length in March 1985, explaining that UQP had previously lost valuable authors to British houses because it had no viable quality paperback imprint. One of Muller's first initiatives was to launch UQP's own quality literary paperbacks, which included A Descant for Gossips. UQP had not been able to sell The Acolyte so it pulped its remaining hardback stock and reissued The Acolyte as part of its paperback imprint. In contrast, The Item from the Late News was set as a HSC text in NSW in 1986, 1988-89 and 1994, which meant it was reprinted in late 1987, and again thereafter.

\footnotetext{
${ }^{6}$ For a fuller discussion on Penguin Australia's relationships with its associates, see Louise Poland and Ivor Indyk.
} 
'I'm beginning to think the only way to get publicity for a novel is to tear into Queensland' wrote Thea Astley to Penguin Books Publishing Director Brian Johns in 1983 (Penguin, 04.11.83). Astley had been interviewed for the University of Queensland newssheet and asked what she thought of the city of Cairns, to which she had replied that it was 'full of Real Estate Agents and hookers'. 'All hell broke loose' she wrote, resulting in more publicity than she bargained for. This letter to Johns was one of several in which she expressed her frustration at the inadequate publicity given to her books by either Penguin or UQP. Johns was quick to respond to Astley's anxieties. Penguin had taken paperback rights to Astley's collection of short stories, Hunting the Wild Pineapple, on modest terms (after Nelson published the hardback version). Sales had been better than average; the hardback had almost sold out in Queensland by March 1980. Johns discussed Astley's concerns with publicist, Julie Steiner. Follow-up promotion was always very difficult to get, he explained to Astley, for books Penguin did not originate. Astley decided to offer her next manuscript, 'Beachmasters', to Penguin, not UQP. Her reasoning here, she explained, was partly nostalgia; her parents' library had been full of Penguins. Yet, what if Astley had stayed with UQP? D'Arcy Randall's significant contribution as UQP's fiction editor to the publication of women's writing in the ensuing decade, which saw the publication of works by Olga Masters, Elizabeth Jolley, Beverley Farmer and more, meant that UQP authors were included centrally in the 'third surge' in Australian writing. Brian Matthews has identified this surge as 'the voice of second-wave feminism whose tones many women writers convey with great assurance' (in Whitlock, xii).

'Beachmasters' might have things that Penguin wanted altered or changed, and 'someone outside the damn book always has a better eye', wrote Astley to Jackie Yowell, Penguin's senior editor (Penguin, 02.04.1984). When Penguin offered Astley only a 10\% royalty, however, she complained but Yowell explained the difference between Penguin's offer and UQP's earlier contract. Penguin's US affiliate, Viking, had agreed to publish 15000 copies of Beachmasters, and Penguin UK was interested in the book, too. Astley went on to develop an excellent working relationship with Brian Johns, Jackie Yowell and the freelance editor, Carla Taines. Yowell advised the use of an agent; Astley was to follow her advice but nearly a decade after her male peers David Malouf and Peter Carey had appointed their own agents. Astley remained adamant about the need for more publicity, and believed that if her novels were published first in hardback in the US, they would be reviewed. Astley hoped an agent would free her from administrative tasks and find her audience, but the results for Astley, her Australian publishers, and her American readership were mixed.

Brian Johns expressed dismay at Astley's decision to appoint Australian agent, Jill Hickson, who worked with New York agent, Elise Goodman. He was concerned that this would lead to complications in Penguin's attempts to encourage other Penguin offices - in UK and the USA - to publish Astley in their own right or take run-on copies from Penguin's Australian print run. The sale of territorial rights could lead to Astley being courted by another publisher. His hunch was correct. American rights to It's Raining in Mango were sold to Putnam's (Stacey Creamer). As Poland and Indyk have found, '[i]t was in the interests of the literary agents to split rights and operate territory-by-territory to maximise their returns, but this was in direct opposition to the interests of multinational publishers' such as Penguin (313). With world rights, Penguin Australia was in a stronger position to work with affiliates and economise (or, as in the case of UQP, negotiate sales of rights on its own terms). The negotiations between Penguin Australia (Jackie Yowell and Peg McColl), Putnam's Stacey Creamer and Elise 
Goodman, however, ensured the co-publishing agreement was fairly harmonious in this instance.

Just as Astley's writing career spanned key transformations in publishing in Australia, her life and work spanned several generations in feminism. Much has been written about Astley's portrayal of women, the gender of her narrative voice, the nature of her feminism in a literary context and as a critique of modernity, and her religious impulse. Questions have been raised, too, about an early lack of academic critical reception for Astley's work. Astley has addressed the issue historically:

I started writing at the wrong time- - before the feminist movement got underway, when women writers tended to be ignored. Later feminism got going and so did the interest in Australian writing. But by then everyone thought: That's just old Thea, she's been around for years. (Astley, UQP promotion file)

Astley and Davis were in many ways literary 'trailblazers' before the second wave of the Australian women's movement. Many of their strategies did not directly challenge and overturn the conventions and prescriptions of gender; the importance of their work was not readily recognised by the 1970 s generation of feminist readers. Astley and Randall produced one of the most potent critiques of masculinist culture in Australian literature. Yowell's editorial support was crucial to Astley's success with Penguin just as Carla Taines' freelance editorial work was to the high literary standards Astley maintained; Yowell also facilitated Astley's understanding of changes in the publishing industry. Yet none of these in-house editors were responsible for publicising Astley's fiction, even though each was a strong advocate of Astley's writing and Davis's backing and networks encouraged early reviews.

Nettie Palmer often argued that readers and critics (we would add editors and publishers) are needed as well as writers to sustain and develop a creative culture (whether in the UK, America or Queensland). How possible was a wider readership in Astley's time? Surely her contemporaries, especially the women of her generation, were those we might expect to have bought and read Astley's work? Surely, too, these were the women whose worldviews and economic prospects were narrowed and prescribed by global depression, war and inequality, even British domination of the publishing industry? Astley understood that a publisher could 'make or break writers, by wide publicity' (1986, 93); while an analysis of sales budgets along gender lines and transnationally might be interesting, the processes of creating a thriving cultural economy are more complex.

Feminist readers and critics not only have to address Astley's feminism being out of kilter with the second wave but account for generational differences. Yet with an increasing recognition of the diversity and complexity of imagined Queensland, especially the far north (after decades of disparagement of the banana republic), we also need to revisit the strengths of Astley's tropical imagination. Astley often, but not always, used the tropics as 'a site of difference' in her work, but how strategic was this? How much did her use of the tropics, her association with the tropics, impact on her southern — and international-readership and reputation? 


\section{Works Cited}

Astley, Thea. 'Tribute to Beatrice Davis'. Tributes 1974 [manuscript] MS 4530, National Library of Australia.

---. 'Travelling Even Farther North: David Williamson You Must Have Stopped at the Border'. Meanjin. 41.4, 1982: 439-441.

---. 'An Interview with Thea Astley'. Norma Jean Richey. South Central Review. 3, 2 (1986): 90-102. http://www.jstor.org/stable/3189369 (1 June, 2013).

---. Thea Astley Collection. UQFL97, Fryer Library, University of Queensland.

Buckridge, Patrick and Belinda McKay (eds). By the Book: A Literary History of Queensland. St. Lucia, Qld: UQP, 2007.

Carter, David and Anne Galligan (eds). Making Books: Contemporary Australian Publishing. St. Lucia, Qld: UQP, 2007.

Dixon, Robert and Katherine Bode (eds). Resourceful Reading: The New Empiricism, eResearch and Australian Literary Culture. Sydney: Sydney University Press, 2009.

Jordan, Deborah. 'American Dreams and the University of Queensland Press'. Reading Across the Pacific: Australia-United States Intellectual Histories. Eds. Robert Dixon and Nicholas Birns. Sydney: Sydney University Press, 2010: 323-339.

Kent, Jacqueline. 'Editors and Authors'. Paper Empires: A History of the Book in Australia, 1946-2005. Eds. Craig Munro, and Robyn Sheahan-Bright. St. Lucia, Qld: UQP, 2006.

Lamb, Karen. "Yrs Patrick": Thea Astley's Brush with Timely Advice on "the rackety career of novel writing". Southerly. 72.1 (2012): 53-65.

Lever, Susan. 'Ratbag Writers and Cranky Critics: In Their Praise'. JASAL. 4 (2005): 11-22 http://pandora.nla.gov.au/pan/63067/200909101633/www.nla.gov.au/openpublish/index.php/jasal/article/view/44/46.html (1 June, 2013).

Lindsay, Elaine. Rewriting God: Spirituality in Contemporary Australian Women's Fiction. Amsterdam: Rodopi, 2000.

Munro, Craig (ed.). UQP: The Writer's Press, 1948-1998. St. Lucia, Qld: UQP, 1998.

Penguin Books Archive, Melbourne, Victoria.

Poland, Louise. 'Publishing for Posterity: Beatrice Davis and Angus and Robertson (19371973)'. Journal of Publishing 2. Australian Special Issue. 2007: 114-142. 
Poland, Louise and Ivor Indyk. 'Rejected by America? Some Tensions in AustralianAmerican Literary Relations'. Reading Across the Pacific: Australia-United States Intellectual Histories. Eds. Robert Dixon and Nicholas Birns. Sydney: Sydney University Press, 2010: 309-322.

Pollak, Michael and Margaret MacNabb. Hearts and Minds: Creative Australians and the Environment. Sydney: Hale \& Iremonger, 2000.

Sheahan-Bright, Robyn. 'For Children and Young Adults', Paper Empires: A History of the Book in Australia, 1946-2005. Eds. Craig Munro, and Robyn Sheahan-Bright. St. Lucia, Qld: UQP, 2006.

Sheridan, Susan. Nine Lives: Postwar Women Writers Making Their Mark. St. Lucia, Qld: UQP, 2011.

Sheridan, Susan and Paul Genoni (eds). Thea Astley's Fictional Worlds. Newcastle upon Tyne: Cambridge Scholars Press, 2006.

Taylor, Cheryl. 'Thea Astley's Poetry: A Prequel to Her Fiction' http://eprints.jcu.edu.au/17191/2/17191_Taylor_2011.pdf (1 June, 2013).

University of Queensland Press Files, UQFL 198, Fryer Library, University of Queensland.

Whitlock, Gillian. Eight Voices of the Eighties: Stories, Journalism and Criticism by Australian Women Writers. St. Lucia, Qld: UQP, 1989. 